\title{
ANALISIS KESALAHAN BERBAHASA PADA PENULISAN AUTOBIOGRAFI KARYA MAHASISWA PROGRAM STUDI TADRIS BAHASA INDONESIA IAIN SURAKARTA
}

\author{
Nazilla Isni Nurrahmi, Endang Rahmawati \\ nazillaisni@gmail.com,erharahmawati@gmail.com \\ IAIN Surakarta
}

Diserahkan: 04 Januari 2021, Direvisi: 29 April 2021, Diterima: 22 Juni 2021

\begin{abstract}
This study aims to describe language errors in autobiographical writing as well as the factors behind the occurrence of language errors by Indonesian Language Tadris students 2018 IAIN Surakarta. This type of research uses a qualitative descriptive method. Data collection techniques in this study were reading, interviewing and taking notes. The validity of the data used theoretical triangulation. This study uses the theory of Setyawati, Matanggui, Zaenal Arifin and Tarigan. The data analysis technique used is an interactive model. The results of the research and data analysis on Language Errors in Autobiographical Writing by Students of the IAIN Surakarta Language Study Program, the researcher found 483 error cases including 54 morphological errors, 25 phonological errors, 463 syntactic errors, 8 semantic errors and 5 discourse errors. Whereas in the data analysis, 50 data were taken and 10 errors were found in the morphological level of the prefix removal, 11 errors in the phonological level in the addition of consonant phonemes, 36
\end{abstract}


syntactic errors in the use of excessive or redundant words, 4 errors in semantic level in incorrect word selection and cases of errors in the level of discourse in the word order or sentence patterns that are not right. The factors underlying the occurrence of language errors include (1) being affected by the language that was mastered first, (2) the speaker's lack of understanding of the language, (3) the lack of proper language teaching.

Keywords: Language Errors, Autobiography, TBI

\begin{abstract}
Abstrak
Penelitian ini bertujuan untuk mendeskripsikan kesalahan berbahasa dalam penulisan autobiografi serta faktor yang melatarbelakangi terjadinya kesalahan berbahasa oleh mahasiswa Tadris Bahasa Indonesia tahun 2018 IAIN Surakarta. Jenis penelitian ini menggunakan metode deskriptif kualitatif. Teknik pengumpulan data dalam penelitian ini adalah membaca, wawancara, dan mencatat. Keabsahan data menggunakan triangulasi teori. Penelitian ini menggunakan teori dari Setyawati, Matanggui, Zaenal Arifin dan Tarigan. Teknik analisis data yang digunakan adalah model interaktif. Hasil penelitian menemukan 483 kasus kesalahan yang meliputi 54 kesalahan morfologi, 25 kesalahan fonologi, 463 kesalahan sintaksis, 8 kesalahan semantik dan 5 kesalahan wacana. Pada analisis data diambil sebanyak 50 data dan ditemukan 10 kesalahan tataran morfologi pada penghilangan prefiks, 11 kesalahan tataran fonologi pada penambahan fonem konsonan, 36 kesalahan sintaksis pada penggunaan kata yang berlebihan atau mubadzir, 4 kesalahan tataran semantik pada pemilihan kata yang tidak tepat dan 1 kasus kesalahan tataran wacana pada susunan kata atau pola kalimat yang tidak tepat. Adapun faktor yang melatarbelakangi terjadinya kesalahan berbahasa antara lain (1) terpengaruh bahasa yang dikuasai lebih dulu, (2) kurangnya pemahaman penutur terhadap bahasa, (3) kurang tepatnya pengajaran bahasa.
\end{abstract}

Kata Kunci: Kesalahan Berbahasa, Autobiografi, TBI. 


\section{PENDAHULUAN}

Bahasa adalah alat interaksi yang dimiliki manusia untuk berkomunikasi. Terkait dengan hal komunikasi, bahasa adalah sistem lambang bunyi yang bebas dipergunakan oleh masyarakat untuk berinteraksi, bekerjasama dan mengidentifikasi suatu hal atau permasalahan. Dalam komunikasi terdapat penutur dan lawan tutur. Mengingat bahasa merupakan hal yang bersifat dinamis, maka perkembangan ilmu pengetahuan beserta teknologi yang semakin maju menghasilkan media informasi yang semakin modern.

Dalam berhubungan secara lisan maupun tulis, setiap orang memanfaatkan kemampuan berbahasa yang ada. Keterampilan berbahasa yang harus dikuasai seseorang terlebih kaum terpelajar yaitu: (1) menyimak, (2) berbicara, (3) membaca dan (4) menulis. Keterampilan menulis adalah kegiatan berupa menciptakan informasi atau catatan dengan menggunakan huruf, menurut Ahmad dan Alek (2016: 62). Pendapat menurut Muthowiatin, dkk dalam Arianti (2020: 3) menulis merupakan kegiatan yang dapat dituangkan melalui instrumen yaitu bahasa. Menulis merupakan keterampilan yang rumit untuk dikuasai, karena keahlian menulis mencakup faktor kebahasaan serta faktor eksternal bahasa di mana keduanya harus runtut dan padu sehingga menghasilkan karangan yang baik. Menurut pengalaman penulis, dalam menulis terkadang ditemukan kecacatan konstruksi kalimat, pembentukan kata, penulisan kata, ejaan dan keterkaitan paragraf. Di samping itu jika kemampuan seseorang mengenai bahasa terbilang rendah, kemungkinan akan terjadi suatu kecacatan atau biasa disebut kesalahan berbahasa.

Kesalahan berbahasa merupakan suatu tindakan berbelok di luar asas penggunaan bahasa baik ujaran maupun catatan. Penyimpangan tersebut termasuk dalam penyimpangan norma kemasyarakatan dan aturan bahasa Indonesia (Setyawati, 2010: 13). Kecacatan atau kesalahan berbahasa dibagi menjadi lima. Chaer (2012: 18) memaparkan beberapa jenis kesalahan berbahasa antara lain: semantik, sintaksis, fonologi, morfologi, dan wacana. Kesalahan atau kecacatan berbahasa sering terjadi pada suatu hal 
yang menyangkut keteraturan kaidah berbahasa seperti pemelajaran bahasa di kelas, penulisan karangan, serta interaksi pendidik dan peserta didik. Kegiatan tersebut tidak hanya mengutamakan komunikasi antara penutur dan lawan tutur, melainkan penguasaan berbahasa seseorang.

Menurut Ghufron (2015: 17), kesalahan berbahasa dapat terjadi karena pembelajaran bahasa, baik bahasa ibu maupun bahasa kedua. Senada dengan Ghufron, Setyawati (2010: 13-14) berpendapat bahwa kesalahan berbahasa dipengaruhi oleh berbagai faktor antara lain (1) terpengaruh bahasa yang dikuasai terlebih dahulu. Seperti bahasa pertama mempengaruhi bahasa kedua yang sedang dipelajari seseorang, maka kesalahan terletak pada pengaruh bahasa pertama. (2) kurangnya pemahaman penutur terhadap bahasa yang digunakan. Kebanyakan penutur tidak memahami kaidah kebahasaan sehingga menyebabkan kesalahan berbahasa, (3) kurang tepatnya pengajaran bahasa. Hal tersebut berkaitan dengan materi yang diajarkan, dalam pemelajaran sifat malas penutur dalam menggunakan kalimat yang tidak efektif, tidak memiliki pengetahuan konstruksi bahasa, asal mengikuti orang lain, serta terpengaruh bahasa asli dari tempat mereka berasal.

Sudah sepantasnya sebagai kaum berpendidikan diharuskan untuk mampu memakai bahasa Indonesia yang sesuai dengan asas kebahasaan dalam mengomunikasikan segala sesuatu. Menurut Septiana, dkk (2015: 3) pemakaian bahasa Indonesia yang baik dan benar merupakan cermin dari pengguna bahasa terhadap bahasa Indonesia yang dituturkan. Apabila masih terdapat kecerobohan yang terjadi menunjukkan penutur masih kurang mempunyai pandangan positif terhadap bahasa Indonesia.

Kegiatan penyusunan autobiografi karya mahasiswa program studi Tadris Bahasa Indonesia masih terdapat kesalahan. Maka dari itu peneliti ingin menganalisis kesalahan berbahasa pada penulisan karya mahasiswa Tadris Bahasa Indonesia.

Dipilihnya penulisan autobiografi mahasiswa Tadris Bahasa Indonesia tahun 2018 karena banyak mahasiswa masih mengabaikan 
ejaan dan diksi dalam berbahasa Indonesia. Padahal, dalam penyampaiannya dibutuhkan penggunaan bahasa yang baik dan benar. Faktor lain dipilihnya mahasiswa Tadris Bahasa Indonesia yaitu adanya mahasiswa asing asal Thailand. Hal ini juga dapat berpengaruh pada kemampuan berbahasa mahasiswa. Maka dari itu peneliti memilih judul Analisis Kesalahan Berbahasa pada Penulisan Autobiografi Karya Mahasiswa Program Studi Tadris Bahasa Indonesia Institut Agama Islam Negeri Surakarta.

\section{KAJIAN LITERATUR}

Adapun teori-teori yang dianggap relevan dalam penelitian Analisis Kesalahan Berbahasa pada Penulisan Autobiografi Karya Mahasiswa Program Studi Tadris Bahasa Indonesia IAIN Surakarta antara lain; Hakikat Kesalahan Berbahasa, Menulis Karangan, dan Autobiografi.

\section{HAKIKAT KESALAHAN BERBAHASA}

Bahasa yang baik merupakan tujuan setiap negara yang sudah pasti segala sesuatunya sejalan dengan ketentuan atau asas yang berlaku serta sesuai dengan penggunaannya, menurut Setyawati (2010: 9). Senada dengan Setyawati, Matanggui dan Arifin (2015: 14) berpendapat bahwa bahasa yang baik adalah bahasa yang berpedoman serta berpegang teguh dengan aturan dan prinsip yang ada. Analisis kesalahan bertujuan untuk membantu pengajar menghadapi permasalahan berbahasa (Tobing, 2003: 328). Berdasarkan pengertian di atas, ditemukan konklusi bahwa pada dasarnya bahasa yang baik adalah bahasa yang segala sesuatunya sepadan dengan aturan serta norma yang telah ditetapkan dan harus memperhatikan situasi pemakaian yang bertujuan untuk membantu pengajar menghadapi permasalahan berbahasa.

Setyawati (2010: 13) memaparkan bahwa kesalahan berbahasa adalah suatu penyimpangan yang disebabkan oleh kurangnya pengetahuan mengenai bahasa maupun faktor lainnya yang dilakukan saat bertutur ataupun secara tertulis. Markhamah dan 
Sabardila (2010: 45) berpendapat bahwa kesalahan berbahasa adalah aktivitas pembelokan atau distorsi berkarakter sistematis, stabil, serta mencitrakan keahlian seseorang yang belum sempurna. Di samping itu kekeliruan ialah pelanggaran yang tidak logis pada perilaku bahasa.

Kesalahan berbahasa tidak hanya terjadi pada penutur asli, namun juga pada pemelajar asing. Namun, kesalahan berbahasa didominasi oleh pemelajar bahasa kedua atau asing. Menurut penelitian mengenai kesalahan berbahasa, unsur pelanggaran yang acap kali terjadi yakni pelanggaran aspek ejaan, morfologi, semantik dan sintaksis (Anjarsari, 2013: 2). Kesimpulan dari beberapa pendapat di atas, kesalahan berbahasa merupakan penyimpangan dalam berbahasa yang terjadi karena beberapa penyebab dan terbagi menjadi beberapa tataran yaitu morfologi, fonologi,semantik, sintaksis dan wacana.

Menurut Setyawati dalam Setiawan dan Wixke (2020: 4) Kesalahan berbahasa tataran morfologi merupakan jenis kesalahan berbahasa pada pembentukan kata. kesalahan morfologi diklasifikasikan antara lain:

(a) Pelenyapan imbuhan

Contoh: (Tidak baku) Bunga melati pamerkan keharumannya.

(Baku) Bunga melati memamerkan keharumannya.

(b) Vokal yang seharusnya lenyap namun tidak lenyap Contoh: (Tidak baku) Kita harus mensukseskan acara seminar ini.

(Baku) Kita harus menyukseskan acara seminar ini.

(c) Pelenyapan bunyi yang seharusnya tidak lenyap

Contoh: (Tidak baku) Jangan suka menyontoh PR ku!

(Baku) Jangan suka mencontoh PR ku!

(d) Penukaran morfem

Contoh: (Tidak baku) Siapa yang barusan melap motorku?

(Baku) Siapa yang barusan mengelap motorku? 
(e) Pemendekan morfem

Contoh: (Tidak baku) Setiap bulan UKM Sentra mendapat tawaran nari di acara penting kota.

(Baku) Setiap bulan UKM Sentra mendapat tawaran menari di acara penting kota

(f) Kurang tepatnya penggunaan imbuhan

Contoh: (Tidak baku) Roni belum membayar karena dompetnya tidak kebawa.

(Baku) Roni belum membayar karena dompetnya tidak terbawa.

(g) Kurang tepatnya pembatasan wujud awal atau bentuk dasar

Contoh: (Tidak baku) Jika sudah selesai, buku itu dapat dikesayakan.

(Baku) Jika sudah selesai, buku itu dapat diberikan/ diserahkan kepada saya.

(h) Peletakan imbuhan pada himpunan morfem kurang efisien

Contoh:(Tidak baku) Panitia lomba itu seharusnya dimintai pertanggungan jawab.

(Baku) Panitia lomba itu seharusnya dimintai pertanggung jawaban.

(i) Kata mejemuk berulang

Contoh: (Tidak baku) guru bahasa Indonesia-guru bahasa Indonesia.

(Baku) guru-guru bahasa Indonesia.

Kesalahan berbahasa tataran fonologi merupakan ilmu mengenai bunyi lingual, umumnya kesalahan bidang fonologi berkaitan dengan ejaan dan pelafalan. Beberapa kesalahan dalam pelafalan antara lain:

(a) Modifikasi huruf

Contoh: (Baku) Kamis $\rightarrow$ (Tidak baku) Kêmis

(Baku) Tekad $\rightarrow$ (Tidak baku) Tekat 
(b) Eliminasi huruf

Contoh: (Baku) Makaroni $\rightarrow$ (Tidak baku) Makroni

(Baku) Hilang $\rightarrow$ (Tidak baku) Ilang

(c) Kenaikan atau perluasan huruf

Contoh: (Baku) Makanya $\rightarrow$ (Tidak baku) Mangkanya

(Baku) Delanggu $\rightarrow$ (Tidak baku) nDelanggu

Adapun kesalahan berbahasa tataran semantik yang berfokus pada makna kata.

Contoh: (Tidak baku) Daging korban akan dibagikan setelah salat Zuhur.

(Baku) Daging kurban akan dibagikan setelah salat Zuhur.

Selanjutnya kesalahan berbahasa tataran sintaksis merupakan jenis kesalahan pada susunan kalimat. Beberapa kesalahan sintaksis antara lain

(a) Adanya faktor bahasa asli tempat asal

Contoh: (Tidak baku) Tunggu bentar kalo mau makan, ikannya belon mateng!

(Baku) Tunggu sebentar kalau mau makan, ikannya belum matang/masak!

(b) Ketidaktepatan pemakaian kata depan

Contoh: (Tidak baku) Tolong ambilkan bedak saya pada laci meja itu.

(Baku) Tolong ambilkan bedak saya di laci meja itu.

(c) Struktur kata yang kurang tepat

Contoh: (Tidak baku) Seminar itu diselengarakan di Swiss Bellin Hotel selama tiga hari.

(Baku) Seminar itu diselengarakan di Hotel Swiss Bellin selama tiga hari.

(d) Memakai morfem berlebihan

Contoh: (Tidak baku) Dilarang tidak boleh memotret di sini!

(Baku) Dilarang memotret di sini! 
(e) Menggunakan superlatif berlebihan

Contoh: (Tidak baku) Permainan itu sangat menyenangkan sekali.

(Baku) Permainan itu sangat menyenangkan/

Permainan itu menyenangkan sekali.

(f) Penjamakan yang kurang tepat

Contoh: (Tidak baku) Para kajur-kajur sedang mengikuti sidang terbuka di graha.

(Baku) Para kajur sedang mengikuti sidang terbuka di graha.

(g) Pemakaian bentuk saling berbalasan yang salah

Contoh: (Tidak baku) Sesama pengendara dilarang saling dahulu mendahului.

(Baku) Sesama pengendara dilarang saling mendahului.

Adapun kesalahan berbahasa dalam bidang kalimat antara lain:

(a) Tidak bersubjek

Contoh: (Tidak baku) Untuk acara itu memerlukan biaya yang cukup banyak.

(Baku) Untuk acara itu diperlukan biaya yang cukup banyak.

(b) Tidak berpredikat

Contoh: (Tidak baku) Stasiun Balapan yang dibangun dengan menggunakan teknik arsitektur yang belum pernah digunakan di mana pun.

(Baku) Stasiun Balapan dibangun dengan menggunakan teknik arsitektur yang belum pernah digunakan di mana pun.

(c) Tidak bersubjek dan tidak berpredikat

Contoh: (Tidak baku) Bapak tua itu melihatku aneh. Serta sulit dipahami.

(Baku) Bapak tua itu melihatku aneh serta sulit dipahami. 
(d) Perangkapan subjek

Contoh: (Tidak baku) Masalah itu kami sudah membicarakannya dengan Pimpinan.

(Baku) Masalah itu sudah kami bicarakan dengan Pimpinan

(e) Antara predikat dan objek yang tersisipi

Contoh: (Tidak baku) Kami mengharap atas kehadiran Bapak/Ibu tepat pada waktunya.

(Baku) Kami mengharap kehadiran Bapak/Ibu tepat pada waktunya.

(f) Kalimat tidak masuk akal

Contoh: (Tidak baku) Yang sudah mengerjakan tugas matematika harap dikumpulkan.

(Baku) Yang sudah mengerjakan tugas matematika harap mengumpulkan pekerjaannya.

(g) Kalimat yang memiliki dua arti

Contoh: (Tidak Baku) Mobil direktur yang baru mahal harganya.

(Baku) Mobil yang baru kepunyaan direktur mahal harganya/ Mobil itu kepunyaan direktur yang baru mahal harganya.

(h) Pelenyapan kata hubung

Contoh: (Tidak baku) Melihat hasil ulanganmu, Ibu sangat kecewa.

(Baku) Setelah melihat hasil ulanganmu, Ibu sangat kecewa.

(i) Kata hubung yang mubazir

Contoh: (Tidak baku) Walaupun dia belum makan seharian, tetapi dia masih kuat.

(Baku) Walaupun dia belum makan seharian, ia masih kuat.

(j) Urutan tidak paralel

Contoh: (Tidak Baku) Harga sembako dibekukan atau kenaikan secara bertahap.

(Baku) Harga sembako dibekukan atau dinaikan secara bertahap. 
(k) Menggunakan morfem asing

Contoh: (Tidak baku) Atlast, kita berhasil membuat acara ini sukses.

(Baku) Akhirnya, kita berhasil membuat acara ini sukses.

(1) Tidak diperlukannya pemakaian morfem tanya

Contoh: (Tidak baku) Rania membuka-buka tas dalam mana ia menyimpan bukunya.

(Baku) Rania membuka-buka tas tempat ia menyimpan bukunya.

Terakhir, kesalahan berbahasa tataran wacana yang membahas mengenai sesuatu yang lebih luas dari kalimat. Kesalahan berbahasa tataran wacana antara lain:

(a) Kesalahan kohesi terbagi menjadi kesalahan penggunaan acuan, penggunaan penggantian, ketidakefektifan wacana sebab tiada penghilangan dan pemakaian kata hubung.

Contoh: (Tidak baku) Yosa dan Yosi pergi ke warung makan. Yosa memesan kopi hitam. Yosi juga mau satu. Kemauan mereka tampaknya berbeda.

(Baku) Yosa dan Yosi pergi ke warung makan. Yosa memesan kopi hitam. Yosi juga mau satu. Kemauan mereka tampaknya sama.

(b) Kesalahan koherensi terbagi menjadi wacana tidak koheren Contoh: (Tidak baku) Banyak korban mati dalam kebakaran, dan sampai saat ini masih dilakukan pencarian. Sungguh malang nasib mereka. Semoga amal ibadahnya diterima Tuhan.

(Baku) Banyak korban tewas dalam kebakaran, dan sampai saat ini masih dilakukan pencarian. Sungguh malang nasib mereka. Semoga amal ibadahnya diterima Tuhan. 


\section{MENULIS KARANGAN}

Menulis yaitu suatu aktivitas yang bisa menghasilkan karya yang disebut produktif (Kusmana, 2014: 17). Senada dengan Kusmana, menurut Sardila (2015: 111) menulis merupakan suatu kegiatan inovatif yang bersifat realistis dan dapat mendatangkan manfaat untuk diri sendiri maupun orang lain. Untuk meciptakan tulisan yang baik, pengarang sepatutnya berperan besar atas ide atau gagasan secara keseluruhan serta mengembangkan kreativitas dengan tujuan untuk berkomunikasi secara tidak langsung melalui tulisan. Tujuan menulis lainnya yaitu untuk memecahkan masalah yang dialami pembaca dan memberikan informasi mengenai suatu kejadian. Mengarang adalah suatu kegiatan manusia yang diawali dengan berpikir dan menuangkannya dalam sebuah tulisan yang disusun dengan baik (Widyamartaya, dkk. dalam Dalman, 2015: 85). Dari beberapa penjelasan tersebut disimpulan bahwa menulis karangan adalah sebuah prosedur berpikir dengan memasukkan ide maupun konsep secara tertulis yang bertujuan untuk memberi informasi.

\section{AUTOBIOGRAFI}

Autobiografi adalah sebuah karya nonfiksi yang ditulis secara personal yang ditujukan untuk menceritakan atau mengisahkan tentang dirinya sendiri (Maryadi, dkk. 2009: 47). Adapun menurut Anderson (dalam Ramawati dan Niken, 2017: 12) merupakan prosa berbentuk naratif yang dibuat berdasarkan realita diri sendiri dalam perkembangan kepribadiannya. Autobiografi yang ditulis secara personal maupun tidak merupakan bentuk kesaksian mengenai perjalanan hidup seseorang secara jelas.

Senada menurut Sardila (2015: 110) autobiografi adalah tulisan mengenai cerita hidup seorang tokoh, akan tetapi dikisahkan oleh orang lain yang menyaksikan kisah hidup tokoh tersebut atau karena tokoh tersebut mengisahkan secara langsung kepada penulis mengenai cerita hidupnya. Autobiografi biasanya menceritakan kehidupan seorang tokoh terkenal maupun tidak terkenal, kendati demikian, autobiografi mengenai seseorang mengisahkan beberapa 
masa dan tempat tertentu. Autobiografi dibuat tidak hanya mengenai yokoh sejarah, namun juga mengenai orang yang masih hidup.

Adanya autobiografi adalah hasil dari suatu hal yang terekam dan pantas untuk diceritakan karena tidak semua hal dapat terekam dan tidak pula semua dapat diceritakan. Oleh karena itu, segala sesuatu yang ditulis haruslah dapat dipertanggungjawabkan. Simpulan dari pemaparan autobiografi di atas adalah sebuah karya yang mengisahkan realita tentang dirinya sendiri ke dalam bentuk naratif secara jelas.

\section{METODE PENELITIAN}

Penelitian ini menggunakan pendekatan deskriptif kualitatif dengan metode content analysis atau analisis isi. Penelitian kualitatif adalah penelitian yang dipakai guna meneliti objek yang bersifat alamiah atau natural dengan instrumen penelitiannya adalah peneliti itu sendiri dan menghasilkan penelitian yang lebih menekankan makna (Sugiyono, 2014: 11).

Penelitian yang dilakukan merupakan penelitian kualitatif untuk memperoleh deskripsi dengan proses pengamatan, menelaah dokumen dan wawancara yang berdasar pada pandangan atau pemikiran seseorang. Deskriptif berarti sampel yang diperoleh berupa gambar dan kata dari sejumlah sampel serta memiliki keterkaitan dan dituangkan dalam bentuk tertulis (Moleong, 2017: 11) sehingga penelitian ini termasuk dalam jenis penelitian deskriptif kualitatif dengan isi kutipan sampel untuk menunjukkan gambaran dengan jelas.

Penyajian data sepenuhnya untuk mengidentifikasi jenis kesalahan berbahasa pada penulisan autobiografi karya mahasiswa Tadris Bahasa Indonesia tahun 2018 Institut Agama Islam Negeri Surakarta. Data yang dipakai dalam penelitian ini berupa dokumen kliping autobiografi karya mahasiswa Program Studi Tadris Bahasa Indonesia Institut Agama Islam Negeri Surakarta yang diperoleh dari tugas mata kuliah Dasar-Dasar Komposisi semester satu tahun 2018 sebanyak 40 karangan autobiografi. 
Penelitian ini menggunakan tiga teknik pengumpulan data, yaitu teknik membaca, wawancara dan mencatat. Penelitian yang dilakukan menggunakan teknik analisis data dengan tahapan pengumpulan sampel, penyaringan sampel, mengklasifikasi sampel dan pendeskripsian. Pengklasifikasian atau penyajian sampel berupa kesalahan yang diperoleh melalui pembacaan yang dicatat, setelah itu dikelompokan dalam tataran kesalahan berbahasa serta diikuti penjelasan kesalahan menurut pandangan dan pemikiran peneliti.

\section{HASIL DAN PEMBAHASAN}

Hasi penelitian dan analisis data terhadap Analisis Kesalahan Berbahasa pada Penulisan Autobiografi Karya Mahasiswa Program Studi Tadris Bahasa Indonesia tahun 2018 Institut Agama Islam Negeri Surakarta, peneliti menemukan 483 kesalahan. Kesalahan tersebut meliputi: (1) kesalahan morfologi berjumlah 54 kesalahan, (2) kesalahan fonologi berjumlah 25 kesalahan, (3) kesalahan semantik berjumlah 8 kesalahan, (4) kesalahan sintaksis berjumlah 463 kesalahan, dan (5) kesalahan wacana berjumlah 5 kesalahan.

Pembahasan dalam penelitian ini berbentuk kesalahan berbahasa dalam penulisan autobiografi karya mahasiswa Program Studi Tadris Bahasa Indonesia Institut Agama Islam Negeri Surakarta. Pembahasan pada penelitian ini dilakukan dengan mendeskripsikan data kesalahan yang ditemukan disertai dengan pembenaran dari kesalahan tersebut. Pada penelitian ini, peneliti mengambil sampel kesalahan yang mewakili setiap jenis kesalahan berbahasa untuk dideskripsikan. Hal ini dilakukan karena data kesalahan yang ditemukan cukup banyak.

\section{Kesalahan Berbahasa Tataran Morfologi}

\begin{tabular}{|c|c|l|}
\hline No. & Kode & \multicolumn{1}{c|}{ Data } \\
\hline 1. & B 12 & Saya ingin mensejahterakan keluarga \\
\hline 2. & H 32 & $\begin{array}{l}\text { Sehingga waktu saya umur 5 tahun saya sudah bisa membaca } \\
\text { tulisan tanpa ejaan atau dengan lancer dan saya dapat } \\
\text { membaca AL-Quran dengan lancer dan menghafal do'a, puji- } \\
\text { pujian dan surat-surat }\end{array}$ \\
\hline
\end{tabular}




\begin{tabular}{|c|c|c|}
\hline 3. & $\mathrm{H} 37$ & Pada saat dia menyamar jadi relawan di Palu... \\
\hline 4. & I 01 & Mulai itu saya langsung izin untuk berhenti kerja. \\
\hline 5. & I 04 & $\begin{array}{l}\text { Banyak anak-anak remaja yang mengkonsumsi minuman } \\
\text { keras di situ. }\end{array}$ \\
\hline 6. & I 07 & $\begin{array}{l}\text { Spontan saya pilih untuk melanjutkan kuliah, karena saya } \\
\text { sangat ingin mimpi saya bisa terwujud. }\end{array}$ \\
\hline 7. & L 08 & $\begin{array}{l}\text { Selain hobi main bulu tangkis, ia juga suka sekali menciptakan } \\
\text { puisi... }\end{array}$ \\
\hline 8. & M 06 & $\begin{array}{l}\text { Setelah melakukan latihan karate beberapa kali aku langsung } \\
\text { suka dan sangat tertarik untuk lebih mempelajari gerakan- } \\
\text { gerakan di karate tersebut. }\end{array}$ \\
\hline 9. & $\mathrm{O} 07$ & $\begin{array}{l}\text {...namun beda dengan sekarang Sd tersebut menjadi sd yang } \\
\text { rapuh... }\end{array}$ \\
\hline 10. & O 08 & $\begin{array}{l}\text {...beda dengan zaman sekarang anak SD sudah terpengaruh } \\
\text { dengan Hp orang tuanya. }\end{array}$ \\
\hline
\end{tabular}

(1) Saya ingin mensejahterakan keluarga (B12)

Kalimat (1) menunjukkan kesalahan bunyi yang seharusnya luluh tidak diluluhkan pada kata mensejahterakan. Seharusnya fonem awalnya luluh menjadi bunyi nasal atau bunyi sengau, yaitu /s/ menjadi /ny/, /t/ menjadi /n/, /k/ menjadi /ng/ dan $/ \mathrm{p} /$ menjadi $/ \mathrm{m} /$. Kalimat tersebut dapat diperbaiki menjadi: (1) Saya ingin menyejahterakan keluarga.

(2) Sehingga waktu saya umur 5 tahun saya sudah bisa membaca tulisan tanpa ejaan atau dengan lancer dan saya dapat membaca Al-Qur'an dengan lancer dan menghafal do'a, puji-pujian dan surat-surat pendek (H32)

Kalimat (2) menunjukkan kesalahan penghilangan prefiks ber-yang tidak dieksplisitkan pada kata umur. Kata umur pada kalimat di atas merupakan kata dasar yang menduduki predikat pada kalimat, sedangkan kata surat-surat pendek menunjukkan pengulangan kata majemuk yang tidak tepat.

(3) Pada saat dia menyamar jadi relawan di Palu...( H37) Kalimat (3) menunjukkan kesalahan penyingkatan morf mem-, men-, meng-, meny-dan menge- menjadi $m-$, $n-$-, ng-, ny dan nge- pada kata jadi. Seharusnya dituliskan secara 
lengkap segingga kalimat tersebut dapat diperbaiki menjadi: Pada saat dia menyamar menjadi relawan di Palu...

(4) Mulai itu saya langsung izin untuk berhenti kerja (I01) Kalimat (4) menunjukkan penghilangan prefiks ber- pada kata kerja. Kalimat tersebut dapat diperbaiki menjadi: Sejak itu saya langsung izin untuk berhenti bekerja.

(5) Banyak anak-anak remaja yang mengkonsumsi minuman keras di situ (I04)

Kalimat (5) menunjukkan kesalahan bunyi yang seharusnya luluh tidak diluluhkan pada kata mengkonsumsi. Seharusnya fonem awalnya luluh menjadi bunyi nasal atau bunyi sengau, yaitu /s/ menjadi /ny/, /t/ menjadi /n/, /k/ menjadi /ng/ dan /p/ menjadi /m/. Kalimat tersebut dapat diperbaiki menjadi: Banyak remaja yang mengonsumsi minuman keras.

(6) Spontan saya pilih untuk melanjutkan kuliah, karena saya sangat ingin mimpi saya bisa terwujud (I07)

Kalimat (6) menunjukkan penyingkatan morf mem-, men-, meng-, meny-dan menge- menjadi $m-, n-, n g-$, ny dan ngepada kata pilih. Kalimat tersebut dapat diperbaiki menjadi: Spontan saya memilih untuk melanjutkan kuliah, karena ingin mimpi saya terwujud.

(7) Selain hobi main bulu tangkis, ia juga suka sekali menciptakan puisi... (L08)

Kalimat (7) menunjukkan penghilangan prefiks ber- yang tidak dieksplisitkan pada kata main. Kata main pada kalimat di atas merupakan kata dasar yang menduduki predikat. Kalimat tersebut dapat diperbaiki menjadi: Selain hobi bermain bulu tangkis, ia juga suka sekali menciptakan puisi...

(8) Setelah melakukan latihan karate beberapa kali aku langsung

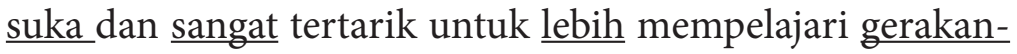
gerakan di karate tersebut (M06)

Kalimat (8) menunjukkan penyingkatan morf mem-, men-, meng-, meny- dan menge- menjadi $m-, n-, n g-$, ny dan ngepada kata suka. Kalimat tersebut dapat diperbaiki menjadi: 
Setelah melakukan latihan karate beberapa kali aku langsung menyukainya dan tertarik untuk mempelajari gerakan dalam karate.

(9) ...namun beda dengan sekarang Sd tersebut menjadi $\underline{\mathrm{sd}}$ yang rapuh...(O07)

Kalimat (9) menunjukkan penghilangan prefiks ber- pada kata beda yang tidak dieksplisitkan. Kalimat tersebut dapat diperbaiki menjadi: ...namun berbeda dengan sekarang Sd tersebut menjadi rapuh...

(10) ...beda dengan zaman sekarang anak SD sudah terpengaruh

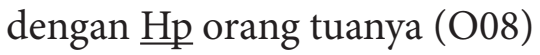

Kalimat (10) menunjukkan penghilangan prefiks ber- pada kata beda yang tidak dieksplisitkan. Kalimat tersebut dapat diperbaiki menjadi: ...berbeda dengan sekarang anak SD sudah terpengaruh dengan ponsel orang tuanya.

Kesimpulan dari analisis kesalahan berbahasa tataran morfologi di atas, kesalahan berbahasa yang sering muncul adalah penghilangan prefiks yang tidak dieksplisitkan sehingga menyebabkan kalimat yang rancu dan seharusnya hal seperti itu tidak terjadi.

\section{Kesalahan Berbahasa Tataran Fonologi}

\begin{tabular}{|c|c|l|}
\hline No. & Kode & \multicolumn{1}{|c|}{ Data } \\
\hline 1. & A 22 & $\begin{array}{l}\text { Tak jarang menjadi buronan tahfidz karena lelah dan ingin } \\
\text { menyerah }\end{array}$ \\
\hline 2. & C 03 & $\begin{array}{l}\text {...kekeluargannya lebih kental dan mengayomi adek- } \\
\text { adeknya... }\end{array}$ \\
\hline 3. & H 06 & $\begin{array}{l}\text { Peluang yang saya miliki adalah saya dapat mengikuti hadroh } \\
\text { dan band lainnya karena saya dapat bernyanyi. }\end{array}$ \\
\hline 4. & H 10 & $\begin{array}{l}\text { Waktu kelas 2 SD saya mengikuti lomba Carlistung } \\
\text { (membaca, menulis, berhitung) }\end{array}$ \\
\hline 5. & H 16 & $\begin{array}{l}\text { Tetapi pada saat kelas 1 SMA saya dipilih Ustadz dan } \\
\text { Uztadzahku untuk mendaftar guru TPA. }\end{array}$ \\
\hline 6. & H 32 & $\begin{array}{l}\text { Sehingga waktu saya umur 5 tahun saya sudah bisa membaca } \\
\text { tulisan tanpa ejaan atau dengan lancer dan saya dapat } \\
\text { membaca AL-Quran dengan lancer dan menghafal do’a, } \\
\text { puji-pujian dan surat-surat pendek. }\end{array}$ \\
\hline
\end{tabular}




\begin{tabular}{|c|c|c|}
\hline 7. & I 08 & $\begin{array}{l}\text { Karena background pendidikan sebelumnya saya adalah } \\
\text { madrasah, maka saya berfikir untuk mendaftar di salah satu } \\
\text { kampus yang bakgroundnya juga agama. }\end{array}$ \\
\hline 8. & J 06 & $\begin{array}{l}\text {...beliau untuk senantiasa menjaga akhlaq dimanapun saya } \\
\text { berada... }\end{array}$ \\
\hline 9. & K 11 & $\begin{array}{l}\text { Ia adalah anak dari ustadz Yusuf Mansur yang } \underline{\text { begitu }} \text { cerdas } \\
\text { dan gigih dalam pendiriannya untuk memberdalam ... }\end{array}$ \\
\hline 10. & W 03 & ...berani mengambil resiko walau itu berbahaya... \\
\hline 11. & Y 09 & $\begin{array}{l}\text {...setelah pulang sekolah dan dilanjut dengan malam } \\
\text { jumatnya kegiatan dzikiran... }\end{array}$ \\
\hline
\end{tabular}

(1) Tak jarang menjadi buronan tahfidz karena lelah dan ingin menyerah (A22)

Kalimat (1) menunjukkan kesalahan pelafalan karena penambahan fonem konsonan /d/ pada kata tahfidz. Kalimat tersebut dapat diperbaiki menjadi: Tak jarang menjadi buronan tahfiz karena lelah dan ingin menyerah.

(2) ...kekeluargaannya lebih kental dan mengayomi adekadeknya... (C03)

Kalimat (2) menunjukkan kesalahan dalam pelafalan karena perubahan fonem pada kata adek sehingga tidak diucapkan sesuai kaidah. Adapun kesalahan sintaksis dalam penjamakan yang ganda pada kata adek-adeknya. Kalimat tersebut dapat diperbaiki menjadi: ...kekeluargaannya lebih kental dan mengayomi adiknya...

(3) Peluang yang saya miliki adalah saya dapat mengikuti hadroh dan band lainnya karena saya dapat bernyanyi (H06)

Kalimat (3) menunjukkan kesalahan pelafalan karena penggantian fonem vokal /a/ pada kata hadroh. Kalimat tersebut dapat diperbaiki menjadi: Peluang yang saya miliki adalah saya dapat mengikuti hadrah dan band lainnya karena saya dapat bernyanyi.

(4) Waktu kelas $2 \mathrm{SD}$ saya mengikuti lomba Carlistung (membaca, menulis, berhitung) (H10)

Kalimat (4) menunjukkan adanya penambahan fonem konsonan /r/ pada kata carlistung (13). Kalimat tersebut dapat 
diperbaiki menjadi: Waktu kelas 2 SD saya mengikuti lomba calistung (baca, tulis, hitung).

(5) Tetapi pada saat kelas 1 SMA saya dipilih Ustadz dan Uztadzahku untuk mendaftar guru TPA (H16)

Kalimat (5) menunjukkan kesalahan pelafalan karena penambahan fonem konsonan /d/ pada kata ustadz dan ustadzahku. Kalimat tersebut dapat diperbaiki menjadi: Tetapi pada saat kelas 1 SMA saya dipilih ustaz dan ustazahku untuk mendaftar guru TPA.

(6) Sehingga waktu saya umur 5 tahun saya sudah bisa membaca tulisan tanpa ejaan atau dengan lancer dan saya dapat membaca Al-Qur'an dengan lancer dan menghafal do'a, puji-pujian dan surat-surat pendek (H32)

Kalimat (6) menunjukkan kesalahan penambahan fonem konsonan ain (yang dilambangkan ') pada kata do'a sehingga mengakibatkan pelafalan yang tidak tepat. Kalimat tersebut dapat diperbaiki menjadi: Sehingga waktu saya berumur 5 tahun sudah bisa membaca tulisan tanpa ejaan dan saya dapat membaca Alquran dengan lancar, menghafal doa, puji-pujian serta surat pendek.

(7) Karena background pendidikan sebelumnya saya adalah madrasah, maka saya berfikir untuk mendaftar di salah satu kampus yang bakgroundnya juga agama (I08)

Kalimat (7) menunjukkan kesalahan dalam pelafalan karena perubahan fonem pada kata berfikir. Kalimat tersebut dapat diperbaiki menjadi: Karena latar belakang pendidikan sebelumnya adalah madrasah, maka saya berpikir untuk mendaftar di kampus yang berlatar belakang agama.

(8) ...beliau untuk senantiasa menjaga akhlaq dimanapun saya berada... (J06)

Kalimat (8) menunjukkan kesalahan dalam pelafalan karena perubahan fonem pada kata akhlaq sehingga tidak diucapkan sesuai kaidah. Kalimat tersebut dapat diperbaiki menjadi: ...beliau untuk senantiasa menjaga akhlak dimanapun saya berada... 
(9) Ia adalah anak dari ustadz Yusuf Mansur yang begitu cerdas dan gigih dalam pendiriannya untuk memberdalam ... (K11)

Kalimat (9) menunjukkan kesalahan dalam pelafalan karena penambahan fonem konsonan /d/ pada kata ustadz. Kalimat tersebut dapat diperbaiki menjadi: Ia adalah anak dari ustaz Yusuf Mansur yang cerdas dan berpendirian teguh untuk memperdalam ...

(10) ...berani mengambil resiko walau itu berbahaya... (W03)

Kalimat (10) menunjukkan kesalahan dalam pelafalan karena perubahan fonem vokal /i/ menjadi /é/ pada kata résiko dan termasuk dalam kata yang tidak baku. Kalimat tersebut dapat diperbaiki menjadi: ...berani mengambil risiko walau itu berbahaya...

(11) ...setelah pulang sekolah dan dilanjut dengan malam jumatnya kegiatan dzikiran... (Y09)

Kalimat (11) menunjukkan kesalahan pelafalan karena penambahan fonem konsonan /d/ pada kata dzikiran. Kalimat tersebut dapat diperbaiki menjadi: ...setelah pulang sekolah dan dilanjut dengan malam jumatnya kegiatan zikiran...

Kesimpulan dari analisis kesalahan berbahasa tataran fonologi di atas, kesalahan berbahasa yang sering muncul adalah penambahan fonem konsonan yang disebabkan oleh penutur menambahkan fonem tertentu pada kata-kata yang diucapkan.

\section{Kesalahan Berbahasa Tataran Sintaksis}

\begin{tabular}{|c|c|l|}
\hline No. & Kode & \multicolumn{1}{|c|}{ Data } \\
\hline 1. & A 06 & $\begin{array}{l}\text { Menjadi satu-satunya anak laki-laki di keluarga, yang } \\
\text { kini tengah bekerja sebagai karyawan swasta salah satu } \\
\text { perusahaan di Karawang }\end{array}$ \\
\hline 2. & A 20 & $\begin{array}{l}\text { Ada cafetaria yang diadakan oleh setiap kelas, menjualkan } \\
\text { makanan buatan sendiri dengan } \\
\text { kantong asrama. }\end{array}$ \\
\hline 3. & C 03 & $\begin{array}{l}\text { dijual murah sesuai } \\
\text { adeknya... }\end{array}$ \\
\hline
\end{tabular}




\begin{tabular}{|c|c|c|}
\hline 4. & D 02 & $\begin{array}{l}\text { Saya ingin menggoreskan senyuman kebahagiaan di wajah } \\
\text { hangat beliau. }\end{array}$ \\
\hline 5. & F 02 & $\begin{array}{l}\text { Terlahir dari keluarga yang sangat sederhana dimana ayah } \\
\text { saya bekerja sebagai buruh pabrik dan ibu saya sebagai ibu } \\
\text { rumah tangga biasa. }\end{array}$ \\
\hline 6. & H 32 & $\begin{array}{l}\text { Sehingga waktu saya umur } 5 \text { tahun saya sudah bisa } \\
\text { membaca tulisan tanpa ejaan atau dengan lancer dan saya } \\
\text { dapat membaca AL-Quran dengan lancer dan menghafal } \\
\text { do’a, puji-pujian dan surat-surat pendek. }\end{array}$ \\
\hline 7. & I 01 & Mulai itu saya langsung izin untuk berhenti kerja. \\
\hline 8. & I 07 & $\begin{array}{l}\text { Spontan saya pilih untuk melanjutkan kuliah, karena saya } \\
\text { sangat ingin mimpi saya bisa terwujud. }\end{array}$ \\
\hline 9. & I 08 & $\begin{array}{l}\text { Karena background pendidikan sebelumnya saya adalah } \\
\text { madrasah, maka saya berfikir untuk mendaftar di salah satu } \\
\text { kampus yang bakgroundnya juga agama. }\end{array}$ \\
\hline 10. & K 11 & $\begin{array}{l}\text { sur yang begitu cerdas } \\
\text { memberdalam } \ldots\end{array}$ \\
\hline 11. & M 06 & $\begin{array}{l}\text { Setelah melakukan latihan karate beberapa kali aku langsung } \\
\text { suka dan sangat tertarik untuk lebih mempelajari gerakan- } \\
\text { gerakan di karate tersebut. }\end{array}$ \\
\hline 12. & $\mathrm{O} 07$ & $\begin{array}{l}\text {...namun beda dengan sekarang Sd tersebut menjadi } \underline{\mathrm{sd}} \\
\text { yang rapuh... }\end{array}$ \\
\hline 13. & O 08 & $\begin{array}{l}\text {... beda dengan zaman sekarang anak SD sudah terpengaruh } \\
\text { dengan } \underline{\text { Hp orang tuanya. }}\end{array}$ \\
\hline 14. & Q 16 & $\begin{array}{l}\text {...dapat menularkan semua ilmu yang saya miliki banyak } \\
\text { orang untuk bekal di akhirat nanti. }\end{array}$ \\
\hline 15. & Q 18 & $\begin{array}{l}\text {...hingga bisa memiliki pengetahuan yang banyak dan dapat } \\
\text { menjadi pemimpin yang bijaksana. }\end{array}$ \\
\hline 16. & $\mathrm{R} 01$ & Tidak ada orangtua manapun yang ingin anaknya... \\
\hline 17. & R 02 & $\begin{array}{l}\text { Dia mempunyai seorang kakak laki-laki yang saat ini sudah } \\
\text { bekerja di Kantor Pelayanan Pajak... }\end{array}$ \\
\hline 18. & $\mathrm{R} 03$ & Kakaknya seorang kakak yang penyayang. \\
\hline 19. & R 05 & $\begin{array}{l}\text { Membaca adalah hobinya, sebenarnya bukan hobi tapi lebih } \\
\text { kepada sebuah kesukaan. }\end{array}$ \\
\hline 20. & S 01 & Tepat pada pukul 10.00 tanggal 4 Januari $2000 \ldots$ \\
\hline 21. & S 15 & $\begin{array}{l}\text { Selama SMA, saya juga tidak aktif dalam mengikuti } \\
\text { perlombaan-perlombaan. }\end{array}$ \\
\hline
\end{tabular}




\begin{tabular}{|c|c|c|}
\hline 22. & Af 16 & $\begin{array}{l}\text { pusing, masuk pertama tidak kenal siapa selain sama faosan } \\
\text { dari Thailand juga, asuk yang ppertama saya buaorang diay } \\
\text { aja terus ada teman-teman tanya dari mana tinggal di mana } \\
\text { yang banyak sekali teman tanya kenapa kamu kuliah di } \\
\text { Indonesia. }\end{array}$ \\
\hline 23. & Af 17 & $\begin{array}{l}\text { Pengumuman yang saya boleh di Indonesia dengan masa } \\
\text { selama } 9 \text { bulan sekarang juga bisa bahasa indonesia } \\
\text { dan bahasa jawa walaupun sedikit sudah pernah lihat } \\
\text { kebudayaan dan pendidikan di Indonesia. }\end{array}$ \\
\hline 24. & Af 20 & $\begin{array}{l}\text { an kalimat tidak } \\
\text { yya. }\end{array}$ \\
\hline 25. & g 02 & $\begin{array}{l}\text { percaya bahwa } \\
\text { paling hebat. }\end{array}$ \\
\hline 26. & 01 & $\begin{array}{l}\text { cita-cita sebagai penyanyi karena } \\
\text { raku bagus, tapi itu dulu waktu aku }\end{array}$ \\
\hline 27. & Ai 09 & tor kedua setelah orangtua ku \\
\hline 28. & Aj 02 & \\
\hline 39. & Aj 03 & dan \\
\hline 30. & $\mathrm{Aj} 09$ & bisnis online... \\
\hline 31. & Ak 02 & $\begin{array}{l}\text { pernah menjadi juara } \\
\text { baru pertama kali me }\end{array}$ \\
\hline 32. & Ak 03 & $\begin{array}{l}\text { Status saya sekarang adalah seorang pelajar mahasiswa } \\
\text { baru... }\end{array}$ \\
\hline 33. & Ak 07 & $\begin{array}{l}\text { fikir terlebih dahulu } \\
\text { ukan sesuatu. }\end{array}$ \\
\hline 34 & Ak 10 & $\begin{array}{l}\text { Menjadi pengusaha yang sukses merupakan harapanku } \\
\text { sejak aku masih kecil. }\end{array}$ \\
\hline 35. & Ak 11 & $\begin{array}{l}\text {...dan berani menangung resiko yang akan terjadi dalam } \\
\text { kegiatan usahanya. }\end{array}$ \\
\hline
\end{tabular}

(1) Menjadi satu-satunya anak laki-laki di keluarga, yang kini tengah bekerja sebagai karyawan swasta salah satu perusahaan di Karawang (A06)

Kalimat (1) menunjukkan kesalahan dalam susunan kata yang tidak tepat. Kalimat tersebut dapat diperbaiki menjadi: 
Menjadi anak lelaki satu-satunya di keluarga, yang kini bekerja sebagai karyawan swasta salah satu perusahaan di Karawang.

(2) Ada cafetaria yang diadakan oleh setiap kelas, menjualkan makanan buatan sendiri dengan dijual murah sesuai kantong asrama (A20)

Kalimat (2) menunjukkan kesalahan dalam penggunaan istilah asing pada kata cafetaria. Dalam kaidah tidak boleh mencampuradukkan bahasa Indonesia dengan bahasa asing. Adapun kesalahan dalam penggunaan unsur yang berlebihan atau mubazir pada kata oleh dan dijual sehingga harus dihilangkan. Selain itu terdapat kesalahan preposisi yang tidak tepat pada kata menjualkan dan kesalahan kalimat tidak logis pada kata sesuai kantong asrama. Hal ini terjadi karea penulis kurang berhati-hati memilih kata. Kalimat tersebut dapat diperbaiki menjadi: Ada kafetaria yang diadakan setiap kelas, menjual makanan buatan sendiri dengan harga murah.

(3) ...kekeluargaannya lebih kental dan mengayomi adekadeknya... (C03)

Kalimat (3) menunjukkan kesalahan dalam penjamakan yang ganda pada kata adek-adeknya. Kalimat tersebut dapat diperbaiki menjadi: ...kekeluargaannya lebih kental dan mengayomi adiknya...

(4) Saya ingin menggoreskan senyuman kebahagiaan di wajah hangat beliau (D02)

Kalimat (4) menunjukkan kesalahan dalam kalimat yang tidak logis. Biasanya penulis kurang berhati-hati dalam memilih kata. Ketidaklogisan terdapat pada kata menggoreskan yang memiliki makna leksikal menggarit dengan benda tajam. Kalimat tersebut dapat diperbaiki menjadi: Saya ingin mengukir senyuman kebahagiaan di wajah hangat beliau.

(5) Terlahir dari keluarga yang sangat sederhana di mana ayah saya bekerja sebagai buruh pabrik dan ibu saya sebagai ibu rumah tangga biasa (F02)

Kalimat (5) menunjukkan kesalahan penggunaan kata tanya yang tidak perlu. Kata tanya yang sering dijumpai yaitu di 
mana, hal mana, yang mana, dari mana dan kata penghubung lain yang disebabkan pengaruh bahasa asing. Pada kalimat di atas terdapat kata tanya di mana yang seharusnya dihilangkan. Kalimat tersebut dapat diperbaiki menjadi: Terlahir dari keluarga yang sangat sederhana. Ayah saya bekerja sebagai buruh pabrik dan ibu saya sebagai ibu rumah tangga.

(6) Sehingga waktu saya umur 5 tahun saya sudah bisa membaca tulisan tanpa ejaan atau dengan lancer dan saya dapat membaca Al-Qur'an dengan lancer dan menghafal $\underline{\text { do'a, }}$ puji-pujian dan surat-surat pendek (H32)

Kalimat (6) menunjukkan kesalahan penggunaan unsur yang berlebihan atau mubazir. Kalimat tersebut dapat diperbaiki menjadi: Sehingga waktu saya berumur 5 tahun sudah bisa membaca tulisan tanpa ejaan dan saya dapat membaca Alquran dengan lancar, menghafal doa, puji-pujian serta surat pendek.

(7) Mulai itu saya langsung izin untuk berhenti kerja (I01)

Kalimat (7) menunjukkan kesalahan dalam penggunaan preposisi waktu yang tidak tepat pada kata mulai. Kalimat tersebut dapat diperbaiki menjadi: Sejak itu saya langsung izin untuk berhenti bekerja.

(8) Spontan saya pilih untuk melanjutkan kuliah, karena saya sangat ingin mimpi saya bisa terwujud (I07)

Kalimat (8) menunjukkan kesalahan dalam penggunaan unsur yang berlebihan atau mubazir pada kata saya sangat dan bisa sehingga harus dihilangkan. Kalimat tersebut dapat diperbaiki menjadi: Spontan saya memilih untuk melanjutkan kuliah, karena ingin mimpi saya terwujud.

(9) Karena background pendidikan sebelumnya saya adalah madrasah, maka saya berfikir untuk mendaftar di salah satu kampus yang bakgroundnya juga agama (I08)

Kalimat (9) menunjukkan kesalahan dalam penggunaan istilah asing pada kata background yang tidak boleh dicampuradukkan dengan bahasa Indonesia serta penggunaan unsur yang berlebihan atau mubazir pada kata saya dan salah satu 
sehingga kalimat menjadi tidak efektif dan harus dihilangkan. Kalimat tersebut dapat diperbaiki menjadi: Karena latar belakang pendidikan sebelumnya adalah madrasah, maka saya berpikir untuk mendaftar di kampus yang berlatar belakang agama.

(10) Ia adalah anak dari ustadz Yusuf Mansur yang begitu cerdas dan gigih dalam pendiriannya untuk memberdalam... (K11) Kalimat (10) menunjukkan kesalahan dalam penggunaan unsur yang berlebihan atau mubazir pada kata begitu dan kesalahan dalam penggunaan preposisi yang tidak tepat pada kata gigih dalam pendiriannya yang kurang sesuai dengan kalimat. Selain itu ditemukan kesalahan dalam penggunaan preposisi tujuan yang tidak tepat pada kata memberdalam. Kalimat tersebut dapat diperbaiki menjadi: Ia adalah anak dari ustaz Yusuf Mansur yang cerdas dan berpendirian teguh untuk memperdalam ...

(11) Setelah melakukan latihan karate beberapa kali aku langsung

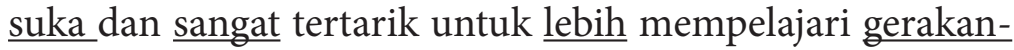
gerakan di karate tersebut (M06)

Kalimat (11) menunjukkan kesalahan dalam penggunaan unsur yang berlebihan atau mubazir pada kata sangat, lebih, di, gerakan dan tersebut sehingga harus dihilangkan. Kalimat tersebut dapat diperbaiki menjadi: Setelah melakukan latihan karate beberapa kali aku langsung menyukainya dan tertarik untuk mempelajari gerakan dalam karate.

(12) ...namun beda dengan sekarang Sd tersebut menjadi sd yang rapuh...(O07)

Kalimat (12) menunjukkan kesalahan penggunan unsur yang berlebihan atau mubazir pada kata sd dan yang sehingga harus dihilangkan. Kalimat tersebut dapat diperbaiki menjadi: ...berbeda dengan sekarang anak SD sudah terpengaruh dengan ponsel orang tuanya.

(13) ...beda dengan zaman sekarang anak SD sudah terpengaruh dengan $\underline{\mathrm{Hp}}$ orang tuanya $(\mathrm{O} 08)$ 
Kalimat (13) menunjukkan kesalahan penggunaan istilah asing pada kata $h p$. Dalam kaidah tidak boleh mencampuradukkan bahasa Indonesia dengan bahasa asing. Kalimat tersebut dapat diperbaiki menjadi: ...berbeda dengan sekarang anak SD sudah terpengaruh dengan ponsel orang tuanya.

(14) ...dapat menularkan semua ilmu yang saya miliki banyak orang untuk bekal di akhirat nanti (Q16)

Kalimat (14) menunjukkan kesalahan dalam kalimat penggunaan unsur yang berlebihan pada kata semua, banyak dan orang sehingga kalimat menjadi tidak efektif dan harus dihilangkan. Adapun kesalahan semantik dalam kesalahan pilihan kata yang tidak tepat pada kata menularkan yang mengakibatkan ketidakpahaman pembaca. Kalimat dapat diperbaiki menjadi: ...dapat menyampaikan ilmu yang saya miliki untuk bekal di akhirat nanti.

(15) ...hingga bisa memiliki pengetahuan yang banyak dan dapat menjadi pemimpin yang bijaksana (Q18)

Kalimat (15) menunjukkan kesalahan dalam penggunaan unsur yang berlebihan atau mubazir pada kata bisa dan dapat yang menyebabkan kalimat menjadi tidak efektif sehingga harus dihilangkan. Adapun kesalahan susunan kata yang tidak tepat pada kata pengetahuan yang banyak. Salah satu penyebab kesalahan susunan kata adalah dipengaruhi oleh bahasa asing. kalimat tersebut dapat diperbaiki menjadi: ...hingga memiliki banyak pengetahuan dan menjadi pemimpin yang bijaksana.

(16) Tidak ada orangtua manapun yang ingin anaknya... (R01) Kalimat (16) menunjukkan kesalahan dalam penggunaan unsur yang berlebihan atau mubazir pada kata manapun yang menyebabkan kalimat menjadi tidak efektif sehingga harus dihilangkan. Kalimat tersebut dapat diperbaiki menjadi: Tidak ada orangtua yang ingin anaknya...

(17) Dia mempunyai seorang kakak laki-laki yang saat ini sudah bekerja di Kantor Pelayanan Pajak... (R02) 
Kalimat (17) menunjukkan kesalahan dalam penggunaan unsur yang berlebihan atau mubazir pada kata seorang dan sudah yang menyebabkan kalimat menjadi tidak efektif sehingga harus dihilangkan. Kalimat tersebut dapat diperbaiki menjadi: Dia mempunyai kakak laki-laki yang saat ini bekerja di Kantor Pelayanan Pajak...

(18) Kakaknya seorang kakak yang penyayang (R03)

Kalimat (18) menunjukkan kesalahan dalam penggunaan unsur yang berlebihan atau mubazir pada kata manapun yang menyebabkan kalimat menjadi tidak efektif sehingga harus dihilangkan. Kalimat tersebut dapat diperbaiki menjadi: Kakaknya seorang yang penyayang.

(19) Membaca adalah hobinya, sebenarnya bukan hobi tapi lebih kepada sebuah kesukaan (R05)

Kalimat (19) menunjukkan kesalahan dalam penggunaan unsur yang berlebihan atau mubazir pada kata sebenarnya bukan hobi tapi lebih kepada sebuah kesukaan yang menyebabkan kalimat menjadi tidak efektif sehingga harus dihilangkan. Kalimat tersebut dapat diperbaiki menjadi: Membaca adalah hobinya.

(20) Tepat pada pukul 10.00 tanggal 4 Januari 2000... (S01) Kalimat (20) menunjukkan kesalahan dalam susunan kata yang tidak tepat pada kata tepat pada pukul 10.00 tanggal 4 Januari 2000... . Salah satu penyebab kesalahan susunan kata adalah dipengaruhi oleh bahasa asing. kalimat tersebut dapat diperbaiki menjadi: 4 Januari 2000 tepat pukul 10.00..

(21) Selama SMA, saya juga tidak aktif dalam mengikuti perlombaan-perlombaan (S15)

Kalimat (21) menunjukkan kesalahan dalam penggunaan unsur yang berlebihan atau mubazir sehingga menjadikan kalimat tidak efektif dan terlalu bertele-tele. Seharusnya kata perlombaan tidak perlu diulang. Kalimat tersebut dapat diperbaiki menjadi: Selama SMA, saya juga tidak aktif dalam mengikuti perlombaan. 
(22) Mulai kuliah hari pertamah, bengong cari gedung dan ruang pusing, masuk pertama tidak kenal siapa selain sama faosan dari Thailand juga, asuk yang ppertama saya buaorang diay aja terus ada teman-teman tanya dari mana tinggal di mana yang banyak sekali teman tanya kenapa kamu kuliah di Indonesia (Af16)

Kalimat (22) menunjukkan kesalahan pada susunan kata yang tidak tepat pada kata mulai kuliah hari pertamah. Salah satu penyebab kesalahan susunan kata adalah dipengaruhi oleh bahasa asing. Adapun kesalahan dalam susunan kata yang tidak tepat pada kata bengong cari gedung dan ruang pusing, masuk pertama tidak kenal siapa selain sama faosan dari Thailand juga, asuk yang ppertama saya buaorang diay aja terus ada teman-teman tanya dari mana tinggal di mana yang banyak sekali teman tanya kenapa kamu kuliah di Indonesia. Salah satu penyebabnya adalah karena pengaruh bahasa asing. kalimat tersebut dapat diperbaiki menjadi: Hari pertama kuliah saya bingung mencari gedung dan ruangan. Belum kenal dengan siapa pun selain faosan yang berasal dari Thailand juga. Lama kelamaan banyak yang bertanya tempat tinggal saya dan mengapa saya kuliah di Indonesia.

(23) Pengumuman yang saya boleh di Indonesia dengan masa selama 9 bulan sekarang juga bisa bahasa indonesia dan bahasa jawa walaupun sedikit sudah pernah lihat kebudayaan dan pendidikan di Indonesia (Af17)

Kalimat (23) menunjukkan kesalahan dalam kalimat yang tidak logis pada kata pengumuman yang saya boleh di Indonesia dengan masa selama 9 bulan sekarang juga bisa bahasa indonesia dan jawa. Biasanya kesalahan kalimat tidak logis terjadi karena penulis kurang berhati-hati dalam pemilihan kata. Hal tersebut juga dapat dipengaruhi oleh penulis yang bukan penutur asli Indonesia sehingga agak sulit. Kalimat tersebut dapat diperbaiki menjadi: Selama 9 bulan di Indonesia, saya dapat berbahasa Indonesia dan Jawa meskipun 
tidak terlalu lancar. Saya sudah pernah melihat budaya dan mengetahui pendidikan di Indonesia.

(24) Kalau ada kalimat tidak sopan susunan kalimat tidak betulan saya mohon maaf sebesar-besar nya (Af20).

Kalimat (24) menunjukkan kesalahan dalam kalimat yang tidak logis pada kata Kalau ada kalimat tidak sopan susunan kalimat tidak betulan. Biasanya kesalahan kalimat tidak logis terjadi karena penulis kurang berhati-hati dalam pemilihan kata. Hal tersebut juga dapat dipengaruhi oleh penulis yang bukan penutur asli Indonesia sehingga agak sulit. Kalimat tersebut dapat diperbaiki menjadi: Apabila ada kalimat yang susunannya kurang baik, saya mohon maaf sebesarbesar nya.

(25) ...satu yang menjadi keyakinannya adalah ia percaya bahwa Allah swt. Merupakan penulis skenario yang paling hebat (Ag02)

Kalimat (25) menunjukkan kesalahan dalam penggunaan superlatif yang berlebihan pada kata yang paling hebat. Kalimat tersebut dapat diperbaiki menjadi: ...satu yang menjadi keyakinannya adalah ia percaya bahwa Allah swt. Merupakan penulis skenario terhebat.

(26) Dulu aku mempunyai cita-cita sebagai penyanyi karena nenek bilang kalau suaraku bagus, tapi itu dulu waktu aku masih kecil (Ai01).

Kalimat (26) menunjukkan kesalahan dalam penggunaan unsur yang berlebihan atau mubadzir pada kata dulu, mempunyai cita-cita, kalau, waktu dan masih. Penggunaan unsur berlebihan membuat kalimat menjadi tidak efektif. Kalimat tersebut dapat diperbaiki menjadi: Aku pernah bercita-cita sebagai penyanyi karena nenek bilang suaraku bagus, tapi itu dulu ketika aku kecil.

(27) Di dalam hidupku motivator kedua setelah orangtua ku adalah seorang... (Ai09) 
Kalimat (27) menunjukkan kesalahan dalam penggunaan unsur yang berlebihan atau mubadzir pada kata di dalam hidupku. Penggunaan unsur berlebihan membuat kalimat menjadi tidak efektif. Kalimat tersebut dapat diperbaiki menjadi: motivator kedua setelah orangtua ku adalah seorang...

(28) ...mudah bergaul kepada semua orang... (Aj02)

Kalimat (28) menunjukkan kesalahan dalam penggunaan preposisi yang tidak tepat. Kalimat tersebut dapat diperbaiki menjadi: ...mudah bergaul dengan semua orang...

(29) Beliau merupakan pembicara terbaik, pelatih suskes dan penulis buku best seller (Aj03)

Kalimat (29)dalam penggunaan istilah asing pada kata best seller. Dalam kaidah tidak boleh mencampuradukkan bahasa Indonesia dengan bahasa asing. Hal ini terjadi karea penulis kurang berhati-hati memilih kata. Kalimat tersebut dapat diperbaiki menjadi: Beliau merupakan pembicara terbaik, pelatih suskes dan penulis buku dengan penjualan terbaik.

(30) Melalui cara-cara itu, saya bisa mempunyai bisnis online... (Aj09)

Kalimat (30) menunjukkan kesalahan dalam penggunaan unsur yang berlebihan atau mubadzir pada kata cara-cara. Penggunaan unsur berlebihan membuat kalimat menjadi tidak efektif. Kalimat tersebut dapat diperbaiki menjadi: Melalui cara itu, saya bisa mempunyai bisnis online...

(31) ...dikarnakan lawan tanding saya merupakan Orang yang pernah menjadi juara di tahun sebelumnya, sedangkan saya baru pertama kali mengikuti ajang perlombaan (Ak02)

Kalimat (31) menunjukkan kesalahan dalam penggunaan unsur yang berlebihan atau mubadzir pada kata orang yang pernah menjadi juara di dan ajang. Penggunaan unsur berlebihan membuat kalimat menjadi tidak efektif. Kalimat tersebut dapat diperbaiki menjadi: ...dikarnakan lawan tanding saya merupakan pemenang tahun sebelumnya, sedangkan saya baru pertama kali mengikuti perlombaan. 
(32) Status saya sekarang adalah seorang pelajar mahasiswa baru... (Ak03)

Kalimat (32) menunjukkan kesalahan dalam penggunaan unsur yang berlebihan atau mubazir sehingga menjadikan kalimat tidak efektif dan terlalu bertele-tele. Kata seorang pelajar seharusnya dihilangkan dan diperbaiki menjadi: Status saya sekarang adalah mahasiswa baru...

(33) ...membuat saya bersemangat, dan berfikir terlebih dahulu sebelum bertindak atau sebelum melakukan sesuatu (Ak07)

Kalimat (33) menunjukkan kesalahan dalam penggunaan unsur yang berlebihan atau mubadzir pada kata terlebih dan atau sebelum melakukan sesuatu. Penggunaan unsur berlebihan membuat kalimat menjadi tidak efektif. Kalimat tersebut dapat diperbaiki menjadi: ...membuat saya bersemangat, dan berpikir dahulu sebelum bertindak.

(34) Menjadi pengusaha yang sukses merupakan harapanku sejak aku masih kecil (Ak10)

Kalimat (34) menunjukkan kesalahan dalam penggunaan unsur yang berlebihan atau mubazir sehingga menjadikan kalimat tidak efektif dan terlalu bertele-tele. Kata yang dan aku masih seharusnya dihilangkan dan diperbaiki menjadi: Menjadi pengusaha sukses merupakan harapanku sejak kecil.

(35) ...dan berani menangung resiko yang akan terjadi dalam kegiatan usahanya (Ak11)

Kalimat (35) menunjukkan kesalahan dalam penggunaan unsur yang berlebihan atau mubazir sehingga menjadikan kalimat tidak efektif dan terlalu bertele-tele. Kata kegiatan seharusnya dihilangkan dan diperbaiki menjadi: ...dan berani menanggung risiko yang akan terjadi dalam usahanya.

Kesimpulan dari analisis kesalahan berbahasa tataran sintaksis di atas, kesalahan berbahasa yang sering muncul adalah penggunaan kata yang berlebihan atau mubadzir sehingga menyebabkan kalimat yang tidak efektif dan tidak bertele-tele. 


\section{Kesalahan Berbahasa Tataran Semantik}

\begin{tabular}{|c|c|l|}
\hline No & Kode & \multicolumn{1}{|c|}{ Data } \\
\hline 1. & H 11 & $\begin{array}{l}\text { Pada waktu kelas 6 SD mendapatkan juara 2 dalam lomba } \\
\text { Tartil AL-Quran tingkat kabupaten }\end{array}$ \\
\hline 2. & H 12 & $\begin{array}{l}\text { Dan waktu TK saya mendapatkan juara 1 lomba pidacil } \\
\text { (pidato kecil) dan Tari Merak. Saya senang sekali karena } \\
\text { saya mendapat piala yang besar }\end{array}$ \\
\hline 3. & H 22 & $\begin{array}{l}\text {...mengikuti lomba empat pilar yaitu Pancasila, UUD 1945, } \\
\text { NKRI dan Tap MPR dan saya mendapatkan juara 3 tingkat } \\
\text { kabupaten dan mendapatkan piala, piagam penghargaan } \\
\text { dan uang tunai... }\end{array}$ \\
\hline 4. & Q 16 & $\begin{array}{l}\text {...dapat menularkan semua ilmu yang saya miliki banyak } \\
\text { orang untuk bekal di akhirat nanti. }\end{array}$ \\
\hline
\end{tabular}

(1) Pada waktu kelas 6 SD mendapatkan juara 2 dalam lomba Tartil AL-Qur'an tingkat kabupaten (H11)

Kalimat (1) menunjukkan kesalahan dalam pilihan kata yang tidak tepat pada penggunaan kata juara dan pemenang. Kata pemenang digunakan untuk orang yang menang bertanding atau berlomba dan tidak dapat dinyatakan orang terpandai di kelas. Kalimat (1) termasuk dalam perlombaan sehingga menggunakan kata pemenang dan kalimat dapat diperbaiki menjadi: Saat kelas 6 SD menjadi pemenang 2 lomba Tartil AL-Qur'an tingkat kabupaten.

(2) Dan waktu TK saya mendapatkan juara 1 lomba pidacil (pidato kecil) dan Tari Merak. Saya senang sekali karena saya mendapat piala yang besar (H12)

Kalimat (2) menunjukkan kesalahan dalam pilihan kata yang tidak tepat pada penggunaan kata juara dan pemenang. Kata pemenang digunakan untuk orang yang menang bertanding atau berlomba dan tidak dapat dinyatakan orang terpandai di kelas. Kalimat (2) termasuk dalam perlombaan sehingga menggunakan kata pemenang dan kalimat dapat diperbaiki menjadi: Saat TK saya menjadi pemenang 1 lomba pidacil (pidato kecil) dan Tari Merak. Saya senang sekali karena mendapat piala besar. 
(3) ...mengikuti lomba empat pilar yaitu Pancasila, UUD 1945, NKRI dan Tap MPR dan saya mendapatkan juara 3 tingkat kabupaten dan mendapatkan piala, piagam penghargaan dan uang tunai... (H22)

Kalimat (3) menunjukkan kesalahan dalam pilihan kata yang tidak tepat pada penggunaan kata juara dan pemenang. Kata pemenang digunakan untuk orang yang menang bertanding atau berlomba dan tidak dapat dinyatakan orang terpandai di kelas. Kalimat (3) termasuk dalam perlombaan sehingga menggunakan kata pemenang dan kalimat dapat diperbaiki menjadi: ...mengikuti lomba empat pilar yaitu Pancasila, UUD 1945, NKRI dan Tap MPR dan saya menjadi pemenang 3 tingkat kabupaten dan mendapatkan piala, piagam penghargaan beserta uang tunai...

(4) ...dapat menularkan semua ilmu yang saya miliki banyak orang untuk bekal di akhirat nanti (Q16)

Kalimat (4) menunjukkan kesalahan dalam kesalahan pilihan kata yang tidak tepat pada kata menularkan yang mengakibatkan ketidakpahaman pembaca. Kalimat dapat diperbaiki menjadi: ...dapat menyampaikan ilmu yang saya miliki untuk bekal di akhirat nanti.

Kesimpulan dari analisis kesalahan berbahasa tataran semantik di atas, kesalahan berbahasa yang sering muncul adalah pemilihan kata yang tidak tepat sehingga menyebabkan makna atau penafsiran yang tidak sesuai.

\section{Kesalahan Berbahasa Tataran Wacana}

\begin{tabular}{|c|c|l|}
\hline No & Kode & \multicolumn{1}{c|}{ Data } \\
\hline 1. & Af 16 & $\begin{array}{l}\text { Mulai kuliah hari pertamah, bengong cari gedung dan ruang } \\
\text { pusing, masuk pertama tidak kenal siapa selain sama faosan } \\
\text { dari Thailand juga, asuk yang ppertama saya buaorang diay } \\
\text { aja terus ada teman-teman tanya dari mana tinggal di mana } \\
\text { yang banyak sekali teman tanya kenapa kamu kuliah di } \\
\text { Indonesia. }\end{array}$ \\
\hline
\end{tabular}

(1) Mulai kuliah hari pertamah, bengong cari gedung dan ruang pusing, masuk pertama tidak kenal siapa selain sama faosan 
dari Thailand juga, asuk yang ppertama saya buaorang diay aja terus ada teman-teman tanya dari mana tinggal di mana yang banyak sekali teman tanya kenapa kamu kuliah di Indonesia (Af16)

Kalimat (1) menunjukkan kesalahan pada susunan kata yang tidak tepat pada kata mulai kuliah hari pertamah. Salah satu penyebab kesalahan susunan kata adalah dipengaruhi oleh bahasa asing. Adapun kesalahan dalam susunan kata yang tidak tepat pada kata bengong cari gedung dan ruang pusing, masuk pertama tidak kenal siapa selain sama faosan dari Thailand juga, asuk yang ppertama saya buaorang diay aja terus ada teman-teman tanya dari mana tinggal di mana yang banyak sekali teman tanya kenapa kamu kuliah di Indonesia. Salah satu penyebabnya adalah karena pengaruh bahasa asing. kalimat tersebut dapat diperbaiki menjadi: Hari pertama kuliah saya bingung mencari gedung dan ruangan. Belum kenal dengan siapa pun selain Faosan yang berasal dari Thailand juga. Lama kelamaan banyak yang bertanya tempat tinggal saya dan mengapa saya kuliah di Indonesia.

\section{PENUTUP}

Berlandaskan pada temuan dan hasil analisis data mengenai analisis kesalahan berbahasa pada penulisan autobiografi karya mahasiswa Program Studi Tadris Bahasa Indonesia tahun 2018 Institut Agama Islam Negeri Surakarta, dapat disimpulkan sebagai berikut.

1. Kesalahan berbahasa pada penulisan autobiografi karya mahasiswa Program Studi Tadris Bahasa Indonesia tahun 2018 Institut Agama Islam Negeri Surakarta. Pada penelitian ini secara keseluruhan, ditemukan 61 kasus kesalahan. Kesalahan morfologi diperoleh sebanyak 10 kesalahan, kesalahan fonologi diperoleh sebanyak 11 kesalahan, kesalahan sintaksis diperoleh sebanyak 35 kesalahan, kesalahan semantik diperoleh sebanyak 4 kesalahan dan kesalahan wacana diperoleh sebanyak 1 kesalahan. Kesalahan tataran morfologi dengan intensitas kesalahan terbanyak 
pada penghilangan prefiks, kesalahan tataran fonologi dengan intensitas kesalahan terbanyak pada penambahan fonem konsonan, kesalahan sintaksis dengan intensitas kesalahan terbanyak pada penggunaan kata yang berlebihan atau mubadzir, kesalahan tataran semantik dengan intensitas kesalahan terbanyak pada pemilihan kata yang tidak tepat dan kesalahan tataran wacana dengan intensitas kesalahan terbanyak pada susunan kata atau pola kalimat yang tidak tepat.

2. Faktor yang mempengaruhi terjadinya kesalahan berbahasa pada penulisan autobiografi karya mahasiswa Program Studi Tadris Bahasa Indonesia tahun 2018 Institut Agama Islam Negeri Surakarta antara lain terpengaruh bahasa yang dikuasai lebih dulu pada kasus kesalahan wacana, karena pada tataran tersebut diidentifikasi hasil karya mahasiswa asal Thailand. Kurangnya pemahaman penutur atau penulis terhadap bahasa yang dipakai, karena hanya serta merta menceritakan mengenai diri sendiri tanpa memperhatikan kosa kata dan kesalahan dalam mengeja kata.

Berlandaskan pada uraian simpulan di atas, maka peneliti menyarankan agar pengarang lebih memperhatikan pemilihan kosa kata serta ejaan yang benar agar menghasilkan tulisan yang baik. Hal ini disebabkan karena karangan tersebut ditulis oleh mahasiswa yang bernotabene kaum terpelajar. Selain itu penelitian ini diharapkan dapat menambah informasi pembaca dalam pemelajaran bahasa aspek kesalahan berbahasa khususnya penulisan autobiografi, serta menambah pengetahuan mahasiswa terkait ketentuan penulisan autobiografi yang baik dan benar. Selain itu yang utama dengan adanya penelitian ini dapat menyadarkan pentingnya analisis kesalahan berbahasa guna menambah pengetahuan secara mendalam mengenai kesalahan berbahasa. Terlebih peneliti merupakan bagian dari mahasiswa Program Studi Tadris Bahasa Indonesia. 


\section{DAFTAR PUSTAKA}

Ahmad dan Alek. 2016. Bahasa Indonesia Untuk Perguruan Tinggi: Substansi Kajian dan Penerapannya. Jakarta: Penerbit Erlangga.

Anjarsari, Nurvita, dkk. 2013. Analisis Kesalahan Pemakaian Bahasa Indonesia Dalam Karangan Mahasiswa Penutur Bahasa Asing Di Universitas Sebelas Maret. Jurnal Basastra. Vol. 1, No.2.

Arianti, Fitria Febri, dkk. 2020. Flipped Classroom Dan Aplikasi Schoology: Analisis Keterampilan Menulis Teks Biografi. Jurnal Tabasa, Vol. 1, No.2.

Ariningsih, Nur Endah, dkk. 2012. Analisis Kesalahan Berbahasa Indonesia Dalam Karangan Eksposisi Siswa Sekolah Menengah Atas. Jurnal Basastra, Vol. 1, No.1.

Chaer, Abdul. 2012. Linguistik Umum. Jakarta: Rineka Cipta.

------, Abdul. 2013. Fonologi Bahasa Indonesia. Jakarta: PT Asdi Mahasatya.

Dalman, H. 2015. Keterampilan Menulis. Jakarta: Rajawali Pers.

Istinganah, Nurul. 2012. Analisis Kesalahan Sintaksis Pada Karangan

Ekspositotis Siswa Kelas VIII SMP 1 Banguntapan, Bantul, Yogyakarta. Yogyakarta: Universitas Negeri Yogyakarta.

Hastuti, Sri. 2003. Sekitar Analisis Kesalahan Berbahasa Indonesia. Jakarta: Balai Pustaka.

Ghufron, Syamsul. 2015. Kesalahan Berbahasa: Teori dan Aplikasi. Yogyakarta: Penerbit Ombak.

Johan, G.M. 2018. Analisis Kesalahan Berbahasa Indonesia Dalam Proses

Diskusi Siswa Sekolah Dasar. Jurnal Pendidikan Bahasa dan Sastra, 18(1),136-149.

Kusmana, Suherli. 2014. Kreativitas Menulis. Yogyakarta: Penerbit Ombak (Anggota IKAPI).

Mahsun. 2005. Metode Penelitian Bahasa: Tahapan Strategi, Metode dan Tekniknya. Jakarta: PT Rajagrafindo Persada. 
Markhamah dan Sabardila, A. 2010. Analisis Kesalahan dan Karakteristik Bentuk Pasif. Surakarta: Jagat Abjad.

Maryadi, dkk. 2009. Model Penggalian Potensi Menulis Melalui Penulisan Otobiografi. Universitas Muammadiyah Surakarta: Jurnal Penelitian Humaniora. Vol. 10, No. 1.

Matanggui, J. Arifin, Zaenal. 2015. Analisis Kesalahan Berbahasa Indonesia. Jakarta: Pustaka Mandiri.

Moleong, Lexy. 2017. Metodologi Penelitian Kualitatif. Bandung: PT Remaja Rosdakarya.

Narbuko dan Achmadi. 2016. Metodologi Penelitian. Jakarta: Bumi Aksara.

Rahmawati dan Niken. 2017. Autobiografi Seorang Konselor Sebagai Asesmen Evaluasi Bimbingan dan Konseling. Yogyakarta: Program Studi Bimbingan dan Konseling Program Pascasarjana Universitas Negeri Yogyakarta. Vol. 1, No. 1.

Rosiana, F.D.A. 2018. Analisis Kesalahan Struktur Kalimat Dan Ejaan Dalam Cerita Pendek Karya Siswa Kelas VIII SMP Kanisius Pakem Sleman Yogyakarta Tahun Ajaran 2016/2017. Skripsi. Yogyakarta: Universitas Sanata Dharma Yogyakarta.

Septiana, Anisa Nur, dkk. 2015. Analisis Kesalahan Struktur Teks dan Pemakaian Bahasa Indonesia Pada Teks Biografi Karya Siswa SMP. Jurnal Basastra, Vol.3, No.3.

Setiawan, Kodrat Eko dan Wixke. 2020. Analisis Kesalahan Berbahasa Indonesia Pada Status Dan Komentar Di Facebook. Jurnal Tabasa. Vol.1, No.1.

Setyawati, Nanik. 2010. Analisis Kesalahan Berbahasa Indonesia. Surakarta: Yuma Pustaka.

Sugiyono. 2014. Memahami Penelitian Kualitatif. Bandung: CV Alfabeta.

-------. 2018. Metode Penelitian Manajemen. Bandung: CV Alfabeta.

Suryana,Yaya. 2015. Metode Penelitian Manajemen Pendidikan. Bandung: CV Pustaka Setia. 
Suryaningsih, Disty. 2018. Analisis Kesalahan Berbahasa dalam Interaksi Pembelajaran Bahasa Indonesia Kelas VII MTs DDI Walimpong Kabupaten Soppeng. Skripsi. Makassar: Universitas Negeri Makassar.

Tarigan, D. dan Tarigan, H.G. 2011. Pengajaran Analisis Kesalahan Berbahasa. Bandung: Angkasa.

Tarigan, Henry Guntur. 2009. Pengajaran Morfologi. Bandung: Penerbit Angkasa.

Tobing, Roswita Lumban. 2003. Analisis Kesalahan Sintaksis Bahasa Prancis oleh Pembelajar Berbahasa Indonesia. Sebuah Studi Kasus. Jurnal Humaniora. Vol. 15.

Wijana, I. 2010. Pengantar Semantik Bahasa Indonesia. Yogyakarta: Program Studi S2 Linguistik Fakultas Ilmu Budaya Universitar Gadjah Mada Yogyakarta. 